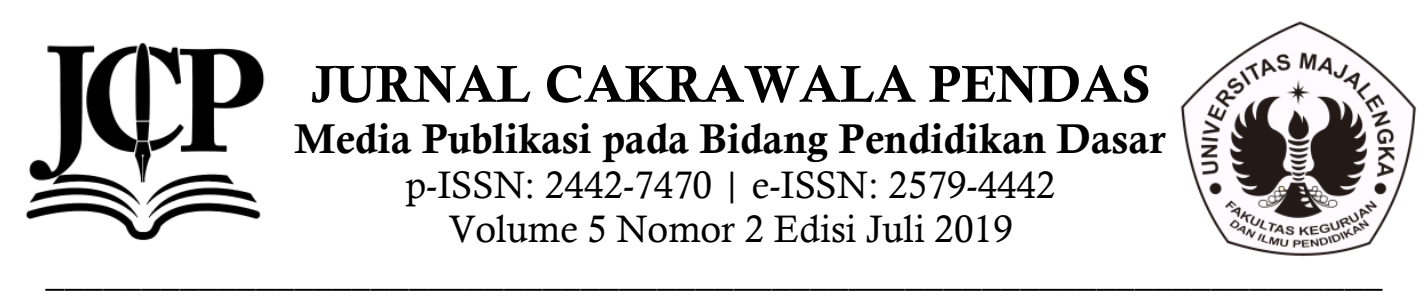

\title{
Bahan Ajar Inquiry Saintifik untuk Berpikir Kritis Siswa Sekolah Dasar
}

\author{
Wina Dwi Puspitasari ${ }^{1}$, Roni Rodiyana ${ }^{2}$ \\ ${ }^{1,2}$ PGSD FKIP Universitas Majalengka \\ E-mail: ${ }^{1}$ winad1211@unma.ac.id, ${ }^{2}$ ronirodiyana@unma.ac.id
}

\begin{abstract}
Abstrak
Penelitian ini merupakan penelitian dan pengembangan menurut Borg dan Gall pada siswa kelas IV Sekolah Dasar. Tujuan penelitian ini adalah mengembangkan bahan ajar berupa buku siswa dan buku guru dengan pendekatan Inquiry Saintifik pada buku terpadu kurikulum 2013 Tema 1 Indahnya Kebersamaan dengan mengetahui kualitas bahan ajar dilihat dari aspek kevalidan para ahli, serta mengetahui kebutuhan siswa dan guru melalui angket kebutuhan dari aspek reliabilitas. Hasil penelitian menunjukkan bahwa kualitas bahan ajar dilihat dari aspek kevalidan berdasarkan penilaian ahli bahasa dan ahli materi termasuk dalam kriteria sangat valid dengan skor rata-rata 86,84\%, keterbacaan oleh siswa dengan melakukan tes pada siswa dengan nilai rata-rata 84 persiswa, analisis kebutuhan guru dengan rata-rata presentase $70,24 \%$. Kesimpulan bahwa bahan ajar inquiry berbasis saintifik terhadap berpikir kritis siswa dapat digunakan dan sudah baik dalam proses pembuatannya serta tingkat keterbacaannya.
\end{abstract}

Kata kunci: Bahan Ajar, Inquiry Saintifik, Berpikir Kritis Siswa. 


\section{Pendahuluan}

Dalam Permendikbud No. 160 Tahun 2014, kurikulum yang dianut pada pendidikan di Indonesia menggunakan dua kurikulum yaitu Kurikulum Tingkat Satuan Pendidikan dan Kurikulum 2013. Dimana pada Kurikulum 2013 mengalami banyak perubahan yang berbeda dengan KTSP. Kurikulum 2013 menekankan pada pembelajaran yang bermakna bagi siswa dan berkarakter pada proses pembelajarannya. Sehingga transformasi dari KTSP ke Kurikulum 2013 dibutuhkan persiapan yang matang, pelatihan, pembiasaan dan ketersedian sumber belajar secara merata. Namun ketersediaan sumber belajar penunjang Kurikulum 2013 masih belum maksimal, salah satunya adalah pengadaan bahan ajar, selain bahan ajar tentu saja guru harus bisa menciptakan suasana pembelajaran yang bermakna, menyenangkan, kreatif, dinamis dan logis (Rodiyana, 2016).

Apabila dilihat dari hasil temuan observasi dan wawancara dengan guru kelas IV buku tersebut masih memilliki keterbatasan terutama dalam pengembangan berpikir kritis siswa. Memang isi dari buku tematik tersebut telah mencakup berbagai macam materi ajar yang dibutuhkan siswa, namun dalam kajian KI dan KD dapat dilihat materi yang ada belum terbilang dapat mengembangkan atau bahkan meningkatkan berpikir kritis siswa. Menurut paga guru, isi dari buku kurikulum 2013 tersebut hanya mencakup sebagian kemampuan yang dapat dilakukan siswa, seperti halnya siswa hanya membaca, berdiskusi, maupun menceritakan, tidak ada unsur proses menganalisis sesuatu dengan kemampuannya maupun memancing rasa ingin tahu siswa akan fenomena-fenomena yang dapat dipecahkan sendiri oleh siswa. Masih banyak sub-sub tema yang tidak memberikan tantangan bagi siswa untuk aktif dan berpikir kritis sesuai kemampuannya.

Gunawan (2013) menyatakan bahwa keterampilan berpikir kritis adalah kemampuan untuk berpikir pada level yang kompleks dan menggunakan proses analisis dan evaluasi. Bukan hanya suasana pembelajarannya saja, namun bahan ajar yang menunjang pun sangat berperan dalam menumbuhkan kemampuan berpikir kritis siswa. Seperti yang telah kita ketahui, berpikir kritis adalah tingkat berpikir dengan level lebih tinggi yang menggunakan analisis dan evalusi, selaras dengan itu strategi dan pendekatan yang dapat disematkan dalam bahan ajar ialah inquiry dimana inquiry menurut Gulo (dalam Trianto, 2010) inquiry berarti suatu rangkaian kegiatan belajar yang melibatkan secara maksimal seluruh kemampuan siswa untuk mencari dan menyelidiki secara sistematis, kritis, logis, analitis sehingga mereka dapat merumuskan sendiri penemuannya dengan penuh percaya diri.

Dari pendapat Gulo tersebut telah terbukti bahwa pembelajaran dengan strategi inquiry siswa dapat mengasah kemampuan berpikir siswa, akan lebih maksimal apabila strategi inquiry ini berbasis saintifik yang dalam pembelajaran siswa harus melalui serangkaian metode ilmiah, dalam langkah metode ilmiah inilah siswa dilatih berpikir kritis yang dimulai dari identifikasi masalah hingga evaluasi permasalahannya. Jadi apabila dalam suatu pembelajaran yang memungkinkan untuk mengembangkan kemampuan berpikir kritis siswa, bahan ajar pun harus menganut inkuiri dan saintifik, sehingga siswa tidak hanya mengandalkan pengetahuan yang terbatasnya saja namun bebas bereksplorasi layaknya ilmuan maupun penemu.

Produk yang dihasilkan dalam penelitian ini adalah bahan ajar inquiry berbasis saintifik untuk meningkatkan berpikir kritis siswa kelas IV Sekolah Dasar. Bahan ajar ini dapat digunakan peserta didik belajar secara mandiri maupun terbimbing oleh guru, dan dikemas sesuai dengan kompetensi pada Kurikulum 2013.

\section{Berpikir Kritis}

Proses berpikir memerlukan proses belajar yang optimal, bahwa belajar ialah suatu proses yang dilakukan oleh individu untuk memperoleh perubahan perilaku yang baru secara keseluruhan, sebagai hasil dari pengalaman individu itu sendiri dalam interaksi dengan lingkungannya sehingga akan menghasilkan pola berpikir kritis dan kreatif (Rodiyana, 2018). 
John Dewey (Fisher, 2008) mendefinisikan berpikir kritis yaitu pertimbangan yang aktif, present (terus menerus) dan teliti mengenai sebuah keyakinan atau bentuk pengetahuan yang diterima begitu saja dipandang dari sudut alasan-alasan yang mendukungnya dan kesimpulan-kesimpulan lanjutan yang menjadi kecenderungan. Sedangkan pandangan Glaser (dalam Fisher, 2008) mendefinisikan berpikir kritis yaitu (1) Suatu sikap mau berpikir secara mendalam tentang masalah seseorang dan hal-hal yang berbeda dalam jangkauan pengalaman seseorang; (2) Pengetahuan tentang metodemetode pemeriksaan dan penalaran yang logis; dan (3) Semacam suatu keterampilan untuk menerapkan metode-metode tersebut. Kemudian menurut Rodiyana (2015) berpikir kritis adalah berpikir beralasan, mencerminkan, bertanggungjawab, kemampuan berpikir yang difokuskan pada pengambilan keputusan terhadap apa yang diyakini atau yang harus dilakukan. Berpikir kritis menuntut upaya keras untuk memeriksa setiap keyakinan atau pengetahuan asumatif berdasarkan bukti pendukungnya dan kesimpulan-kesimpulan lanjutan yang diakibatkannya.

Tiga pendapat di atas dapat disimpulkan mengenai kemampuan berpikir kritis, ialah suatu suatu sikap akan berpikir mengenai suatu hal dengan pertimbangan aktif dan teliti, memerhatikan segala hal yang menyangkut tentang pengambilan keputusan tersebut sehingga tidak menjadi suatu pengetahuan yang asumtif. Asumtif disini berarti bukan sekedar asumsi diri sendiri melainkan melalui proses perumusan masalah, memberikan argumen sesuai fakta, melakukan deduksi dan induksi, melakukan evaluasi baru setelah itu pengambilan keputusan sebagai pemecahan masalah yang dihadapi.

\section{Bahan Ajar}

Menurut Chomsin dan Jasmadi (2011) bahan ajar merupakan seperangkat sarana atau alat pembelajaran yang berisikan materi pembelajaran, metode, batasan- batasan dan cara mengevaluasi yang didesain secara sistematis dan menarik dalam rangka mencapai tujuan yang diharapkan, yaitu mencapai kompetensi atau sub kompetensi dengan segala kompleksitasnya. Bahan ajar menurut Depdiknas (2008: 6) adalah segala bentuk bahan yang digunakan untuk membantu pendidik dalam melaksanakan kegiatan pembelajaran. Selanjutnya menurut Lestari (2013) mengemukakan pendapatnya bahwa bahan ajar adalah seperangkat materi pelajaran yang mengacu pada kurikulum yang digunakan dalam rangka mencapai standar kompetensi dan kompetensi dasar yang telah ditentukan.

Menurut Prastowo (2013), berdasarkan bentuk atau teknologi yang digunakan, bahan ajar dapat dibedakan menjadi empat macam, yaitu bahan cetak (printed), bahan ajar dengar (audio), bahan ajar pandang dengar (audio visual), bahan ajar interaktif (interactive teaching materials). Senada juga menurut Direktorat Pembinaan Sekolah Menengah Atas (2009), bahan ajar dikategorikan menjadi empat yaitu: bahan cetak (printed), bahan ajar pandang dengar (audio visual), bahan ajar multimedia interaktif (interactive teaching material), bahan ajar dengar (audio).

$$
\text { Menurut Panen }
$$

menyebutkan penyusunan bahan ajar dapat dilakukan dengan tiga cara, yaitu menulis sendiri (starting from scratch), pengemasan kembali informasi (information sepackaging), kompilasi penataan informasi (compilation atau wrap around text). Direktorat Jenderal Pendidikan Dasar dan Menengah (Lestari, 2013) bahan ajar memiliki karakteristik sebagai berikut: self instructional, self contained, stand alone, adaptive, user friendly. Djahur Siddiqq (2009) mengemukakan karakteristik dari bahan ajar terdiri dari: mampu membelajarkan sendiri para siswa (self instructional), bahan ajar bersifat lengkap (self contained), mampu membelajarkan peserta didik (self instructional material).

\section{Model Pembelajaran Inquiry}

Menurut Brahim (2010) Inquiry adalah suatu proses untuk memeroleh dan mendapatkan informasi dengan melakukan observasi dan eksperimen untuk mencapai jawaban atau memecahkan masalah terhadap pertanyaan atau rumusan masalah dengan menggunakan berpikir kritis dan logis. Gulo (Trianto, 2010) inquiry berarti suatu rangkaian kegiatan belajar yang melibatkan secara maksimal seluruh kemampuan siswa untuk mencari dan 
menyelidiki secara sistematis, kritis, logis, analitis sehingga mereka dapat merumuskan sendiri penemuanya dengan penuh percaya diri. Menurut Sanjaya (2011) inquiry adalah rangkaian kegiatan pembelajaran yang menekankan pada proses berpikir secara kritis dan analitis untuk mencari dan menemukan jawaban sendiri dari suatu masalah yang dipertanyakan.

Suchman (Joyce, et al, 2007) mengemukakan bahwa tujuan model inquiry ialah mengembangkan keterampilan kognitif dalam melacak dan mengolah datadata. Sound dan Trowbridge (Mulayasa, 2008) mengemukakan tiga macam model inquiry yaitu inquiry terpimpin (guide inquiry), inquiry bebas (free inquiry), inquiry bebas yang dimodifikasi (modified free inquiry). Langkah-langkah pendekatan inquiry menurut Sanjaya (2008) yaitu orientasi, merumuskan masalah, mengajukan hipotesis, mengumpulkan data, menguji hipotesis, merumuskan kesimpulan. Pramudi (2010) mengemukakan pendapatnya mengenai langkah-langkah inquiry yaitu merumuskan masalah, merumuskan hipotesis, mengumpulkan data, menguji hipotesis, merumuskan kesimpulan.

Menurut Ibid (2014) kelebihan pembelajaran inquiry yaitu menekankan pada pengembangan aspek kognitif, afektif, dan psikomotorik secara seimbang; siswa menjadi aktif dalam mencari dan mengolah sendiri informasi; siswa mengerti konsep-konsep dasar dan ide-ide secara lebih baik; memberikan ruang kepada siswa untuk belajar sesuai dengan gaya belajar mereka; siswa yang memiliki kemampuan di atas rata-rata tidak akan terhambat oleh siswa yang lemah dalam belajar; membantu siswa dalam menggunakan ingatan dalam transfer konsep yang dimilikinya kepada situasi-situasi proses belajar yang baru; mendorong siswa untuk berpikir intuitif dan merumuskan hipotesisnya sendiri; dapat membentuk dan mengembangkan konsep sendiri (self-concept) pada diri siswa sehingga secara psikologis siswa lebih terbuka terhadap pengalaman baru, berkeinginan untuk selalu mengambil dan mengeksploitasi kesempatan-kesempatan yang ada.

\section{Pendekatan Saintifik (Scientific Approach)}

Abidin (2013) pendekatan saintifik diartikan sebagai pendekatan pembelajaran yang dikembangkan dengan berdasarkan pada pendekatan ilmiah dalam pembelajaran. bertemali dengan definisi ini, sebelum menguraikan komponen pendekatan pembelajaran saintifik perlu dipahami dulu konsep pendekatan ilmiah dalam pembelajaran. Sedangkan menurut Permendikbud Nomor 81A Tahun 2013 lampiran IV proses pembelajaran ilmiah terdiri atas lima pengalaman belajar pokok yaitu mengamati, menanya, mengumpulkan informasi/eksperimen, mengolah informasi, dan mengkomunikasikan.

\section{Metode Penelitian}

Metode penelitian ini menggunakan penelitian dan pengembangan atau Research and Develompent (R\&D) yang dilakukan pada pengembangan bahan ajar Inquiry Saintifik ini adalah dengan menggunakan model Borg \& Gall. Adapun prosedur penelitian dan pengembangan model Borg \& Gall yang disederhanakan oleh Sugiyono (2016) dan digunakan dalam penelitian ini sebagai yaitu research and inormation colleting, planning, develop preliminary form of the product, preliminari field testing, main product revision, main field testing, operational product revision, operational field testing, final product revision, dissemination and distibution.

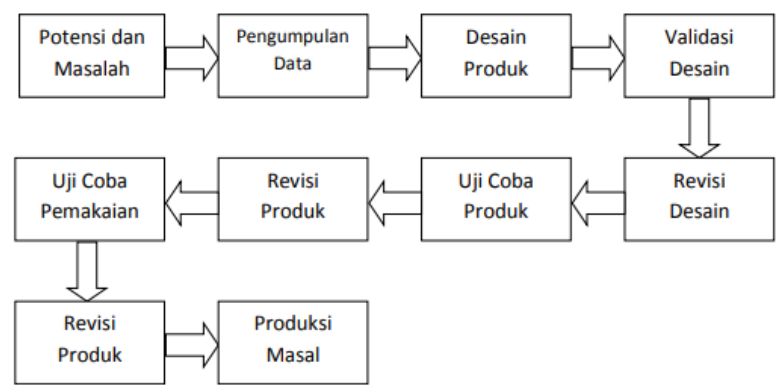

Skema Prosedur Penelitian Pengembangan diadaptasi dari Sugiyono (2016)

a. Sumber Data dan Subjek Penelitian

Sumber data pada penelitan dan pengembangan bahan ajar inkuiri berbasis saintifik dibagi menjadi dua jenis. Data yang pertama berupa kuantitaif yang diperoleh dari pengumpulan data berupa 
skor dari setiap analisis data seperti uji validasi, uji realibitas, dan validasi angket. Data yang kedua berupa kualitatif yang diperoleh dari pengumpulan data berupa saran perbaikan dan tanggapan dari para ahli dan guru. Uji coba subjek dalam penelitian ini adalah peserta didik kelas IV SDN Leuwikidang.

b. Teknik dan Instrumen Pengumpulan Data

Menurut Sukmadinata \& Nana (2010) instrumen penelitian adalah berupa tes yang bersifat mengukur, karena berisi pertanyaan atau pernyataan yang alternatif jawabannya memiliki standar jawaban tertentu, benar salah maupun skala jawaban. Instrumen yang berisi jawaban skala, berupa pertanyaan atau pernyataan yang jawabannya berbentuk skala deskriptif ataupun skala garis. Pengumpulan data tentang kebutuhan siswa dan guru untuk bahan ajar yang akan dikembangkan diperoleh melalui angket yang diujikan kepada Siswa dan Guru. Kedua ahli akan memberikan pendapatnya tentang bahan ajar yang akan dikembangkan.

c. Analisis Data

1) Analisis ini menggunakan angket yang dibagikan kepada guru dan siswa untuk mengetahui kebutuhan adanya bahan ajar muatan lokal yang mengahasilkan data berupa skor atau angka-angka, serta karakteristik guru dan siswa ditentukan dengan menghitung persentase jawaban disetiap pertanyaan. Rumus analisis kebutuhan sebagai berikut:

$\% f=\frac{\mathbf{f}}{\mathrm{N}} \times 100 \%$

Keterangan:

$\% f=$ Persentase kehendak responden

$f=$ Frekuensi jawaban dari responden

$\mathrm{N}$ = Jumlah responden

2) Analisis Data Kevalidan

Data kevalidan bahan ajar akan dianalisis dengan deskriptif presentase dengan rumus yang diadaptasi dari Akbar (2013) sebagai berikut:

$\mathrm{V}=\frac{\mathrm{TS}_{\mathrm{e}}}{\mathrm{TS}_{\mathrm{h}}} \times 100 \%$
Keterangan:

$\mathrm{V} \quad=$ Persentase validitas

Tse $=$ Total skor empiris (jumlah skor penilaian oleh validator)

TSh = Total skor harapan (jumlah skor maksimal)

Tabel. Kriteria Kevalidan

\begin{tabular}{|c|c|c|}
\hline No & Kriteria Validitas & Tingkat Validitas \\
\hline 1. & $85,01 \%=100,00 \%$ & Sangat Valid, atau dapat digunakan tanpa revisi \\
\hline 2. & $70,01 \%=85,00 \%$ & $\begin{array}{c}\text { Cukup Valid, atau dapat digunakan namun perlu direvisi } \\
\text { kecil }\end{array}$ \\
\hline 3. & $50,01 \%=70,00 \%$ & $\begin{array}{c}\text { Kurang Valid, disarankan tidak dipergunakan karena } \\
\text { perlu direvisi besar }\end{array}$ \\
\hline 4. & $01,00 \%=50,00 \%$ & Tidak Valid, atau tidak boleh dipergunakan \\
\hline
\end{tabular}

Akbar (2013: 41)

\section{Hasil Penelitian}

Pembelajaran di kelas IV SDN Leuwikidang Kec. Kasokandel Kab. Majalengka memang telah berbasis saintifik namun pada nyatanya isi dari buku kurikulum 2013 masih terasa sedikit cakupannya dan kurang berhasil menghidupkan kelas, siswapun terkadang masih melakukan kegiatan membaca mandiri saja dan guru yang menjelaskan. Sebagai buku induk dalam pembelajaran kurikulum 2013 seharusnya buku terpadu tematik kurikulum 2013 tersebut memiliki cakupan yang lebih lengkap untuk siswa konsumsi. Dengan saintifik yang telah dimiliki oleh buku tematik terpadu kurikulum 2013 maka akan lengkap apabila cakupan isi materinya ditambahkan dengan cakupan kemampuan berpikirnya, baik itu berpikir kritis maupun berpikir kreatif. Tidak hanya memuat keterampilan dalam percobaan dan penelitian, namun juga memuat kemampuan berpikirnya pun harus ikut serta ditumbuh kembangkan. Karena dalam pembelajaran akan lebih menantang bagi siswa apabila pembelajarnnya memiliki suasana dan nuansa yang menantang pula.

Dalam kurikulum 2013 sudah ditetapkan kompetensi inti dan kompetensi dasar maka pada indikator ditambahkan poin-poin yang dapat melengkapi cakupan materi buku bahan ajar tematik terpadu kurikulum 2013 tersebut. Bahan ajar yang dikembangkan adalah inquiry berbasis saintifik terhadap berpikir kritis siswa dengan cakupan isi materi yang berkaitan dengan pemecahan masalah, percobaan 
dan pengamatan, dengan dikemas menggunakan materi-materi yang luas dan hanya bersifat abstrak serta dapat dikembangkan dan dimodifikasi cakupan isi materinya dengan menambah beberapa indikator didalamnya sehingga buku bahan ajar yang telah memuat pendekatan saintifik tersebut lebih lengkap dengan adanya perpaduan model inquiry dan nuansa berpikir kritis pada soal-soal dan materi didalamnya.

Dari hasil validasi oleh para ahli terhadap bahan ajar inquiry berbasis saintifik terhadap berpikir kritis siswa kelas IV Sekolah Dasar dapat digunakan dalam tahap pengembangan dan revisi. Dalam tahap pengembangan tetap menemukan beberapa kekurangan yang perlu diperbaiki lagi dan validasi dilakukan untuk menghasilkan bahan ajar yang baik, selanjutnya tahap perbaikan bahan ajar yang masih berbentuk draf divalidasi oleh para ahli dengan skor rata-rata $86,84 \%$ tergolong pada kategori sangat valid dengan berdasarkan pada tabel kriteria kevalidan. Berdasarkan dari hasil analisis kebutuhan yang telah dilakukan dapat dirumuskan aspek-aspek yang didapat melalui angket kebutuhan siswa dan kebutuhan guru yaitu materi yang hendak dikembangan berupa bentuk buku; cakupan materi tidak hanya hapalan namun dapat diaplikasikan; judul buku adalah Inquiry Berbasis Saintifik (IBS); terdapat glosarium untuk memudahkan memahami istilah maupun kalimat yang kurang dimengerti.

Menurut Purwanto (2010) konsep berpikir dalam arti yang sempit adalah meletakkan atau mencari hubungan atau pertalian antara abstraksi-abstraksi, berpikir erat hubungannya dengan daya-daya jiwa yang lain seperti dengan tanggapan, ingatan, pengertian dan perasaan. Selanjutnya menurut Paul Mussen dan Mark Rosenzweig (Jalaluddin Rakhmat, 2009) menyatakan bahwa berpikir yakni "The term 'thinking' refers to many kind of activities that involve the manipulation of concept and symbols, representation of objects and events". Sehingga, berpikir menunjukkan berbagai kegiatan yang melibatkan penggunaan konsep dan lambang sebagai pengganti objek dan peristiwa.
Berdasarkan teori belajar dan berpikir kritis di atas, tentu materi berpikir kritis menjadi salah satu hal penting dalam pembelajaran di kelas. Sekarang ini banyak isu-isu bahwa Indonesia sedang mengalami krisis berpikir kritis, maka dari itu bahan ajar inquiry berbasis saintifik ini sangat cocok untuk solusi akan krisis tersebut dengan penanaman secara dini di sekolah dasar agar menjadi bekal yang berharga di lingkungan masyarakat, serta bahan ajar inquiry saintifik ini merupakan terobosan untuk memperbaiki kemampuan berpikir siswa sekolah dasar. Dalam proses belajar siswa dapat memaksimalkan kemampuan berpikir mereka dengan didampingi bahan ajar inquiry saintifik ini secara leluasa. Sehingga bahan ajar inquiry berbasis saintifik ini efektif untuk dapat meningkatkan, memperbaiki dan melatih daya berpikir siswa yang menjadi tunas penting dalam proses kehidupan.

\section{Kesimpulan}

Hasil penelitian menunjukkan bahwa kualitas bahan ajar dilihat dari aspek kevalidan berdasarkan penilaian ahli bahasa dan ahli materi termasuk dalam kriteria sangat valid dengan skor rata-rata $86,84 \%$, keterbacaan oleh siswa dengan melakukan tes pada siswa dengan nilai rata-rata 84 persiswa, analisis kebutuhan guru dengan rata-rata presentase 70,24\%. Kesimpulan bahwa bahan ajar inquiry berbasis saintifik terhadap berpikir kritis siswa dapat digunakan dan sudah baik dalam proses pembuatannya serta tingkat keterbacaannya. Selanjutnya dapat dirumuskan menjadi prinsip-prinsip pengembangan bahan ajar inquiry berbasis siantifik. Pada prinsip-prinsip pengembangan bahan ajar inquiry berbasis saintifik secara umum berisikan mengenai materi dan topik yang dapat meningkatkan kemampuan berpikir kritis siswa, pembelajaran yang bernuansa inquiry saintifik dengan menemukan, Bahan ajar ini dapat dijadikan sebagai salah satu sumber belajar tambahan yang diberikan kepada siswa sebagai buku suplemen buku siswa kurikulum 2013, selain itu evaluasi yang terdapat pada bahan ajar ini mempermudah guru untuk menilai apakah siswa mencapai tujuan 
pembelajaran yang telah direncanakan atau belum mencapai tujuan pembelajaran.

Bahan ajar ini dapat dijadikan sebagai salah satu sumber belajar tambahan yang diberikan kepada siswa sebagai buku suplemen buku siswa kurikulum 2013, selain itu evaluasi yang terdapat pada bahan ajar ini mempermudah guru untuk menilai apakah siswa mencapai tujuan pembelajaran yang telah direncanakan atau belum dalam mencapai tujuan pembelajaran; dapat digunakan sebagai salah satu sumber belajar dalam mengembangkan materi yang ada pada buku siswa dalam rangka untuk mencapai kompetensi belajar yang diharapkan; dapat menambah wawasan dan pengetahuan dalam rangka mengembangkan kajian materi dan penilaian sekaligus sebagai kegiatan ilmiah pengembangan diri sebagai guru profesional yang bertujuan meningkatkan kompetensi dan kecerdasan siswa.

\section{Daftar Pustaka}

Abidin, Y. (2014). Desain Sistem Pembelajaran dalam Konteks Kurikulum 2013. Bandung: PT Refika aditama.

Ade, S. (2011). Model-model Pembelajaran. Jakarta: Bumi Aksara.

Akbar, S. (2013). Instrumen Perangkat Pembelajaran. Bandung: PT. Remaja Rosdakarya.

Andi, PS. (2013). Panduan Kreatif Membuat Bahan Ajar Inovatif. Yogyakarta: Diva Press.

Baharuddin dan Esa NM. (2012). Teori Belajar \& Belajar. Jogjakarta: Ar Ruzz Media.

Dakir. (2010). Perencanaan dan Pengembangan Kurikulum. Jakarta: Rineka Cipta.

Departemen Pendidikan Nasional. (2008). Panduan Pengembangan Bahan Ajar. Jakarta: Direktorat Pembinaan Sekolah Menengah Atas.
Eko P. Widoyoko. (2012). Teknik Penyusunan Instrumen Penelitian. Yogyakarta: Pustaka Pelajar.

Gunawan, Imam. (2013). Metode Penelitian Kualitatif: Teori dan Praktik. Jakarta: Bumi Aksara.

Ibid. (2014). Metode Penelitian. Yogyakarta: Pustaka Pelajar.

Lestari, I. (2013). Pengembangan Bahan Ajar Berbasis Kompetensi Sesuai dengan KTSP. Padang: Akademia Permata.

Jufri, W. (2012). Belajar dan Pembelajaran SAINS. Mataram: Pustaka Reka Cipta.

Majid, A. (2014). Perencanaan Pembelajaran. Bandung: Rosdakarya.

M. Djauhar Siddiq, dkk. (2008). Bahan Ajar Cetak. Jakarta: Direktorat Jenderal Pendidikan Tinggi Departemen Pendidikan Nasional.

Mulyasa, E. (2013). Pengembangan dan Implementasi Kurikulum 2013. Bandung: Remaja Rosdakarya.

Permendikbud No. 160 Tahun 2014 tentang Pemberlakuan Kurikulum Tahun 2006 dan Kurikulum 2013.

Prastowo, A. (2013). Pengembangan Bahan Ajara Tematik. Yogyakarta: Diva Press.

Puspitasari, Wina Dwi. (2015). Metode Pembelajaran Bermain Peran dalam Meningkatkan Kemampuan Ekspresif Drama pada Pembelajaran Bahasa Indonesia. Jurnal Cakrawala Pendas. 1, (1).

Puspitasari, Wina Dwi. (2016). Pengaruh Sarana Belajar Terhadap Prestasi Belajar Ilmu Pengetahuan Sosial di Sekolah Dasar. Jurnal Cakrawala Pendas. 2, (2), 105-120.

Puspitasari, Wina Dwi. (2016). Implementasi Nilai-Nilai Demokrasi di Sekolah Dasar. Repository Prosiding 
Seminar Nasional Pendidikan Dasar. Volume 2, 244-249.

Puspitasari, Wina Dwi. (2018). Implementasi Metode Hypnoteaching untuk Meningkatkan Hasil Belajar Siswa Sekolah Dasar. Jurnal Cakrawala Pendas. 4, (1).

Puspitasari, Wina Dwi. (2018). Implementasi Model Pembelajaran Kooperatif Tipe Student Teams Achievement Divisions Dalam Meningkatkan Hasil Belajar IPS Siswa. Jurnal Cakrawala Pendas. 4, (2), 58-65.

Puspitasari, Wina Dwi. (2019). Efektivitas Penerapan Model Cooperative Integrated Reading and Composition (CIRC) terhadap Pemahaman Konsep Siswa pada Pembelajaran IPS di Sekolah Dasar. Jurnal Cakrawala Pendas. 5, (1).

Rodiyana, Roni. (2015). Pengaruh Penerapan Strategi Pembelajaran Inkuiri Terhadap Kemampuan Berpikir Kritis dan Kreatif Siswa SD. Jurnal Cakrawala Pendas. 1, (1), 34-43.

Rodiyana, Roni. (2016). Penerapan Model Quantum Teaching untuk Meningkatkan Verbal-Linguistik Siswa pada Pembelajaran IPS. Jurnal Cakrawala Pendas. 2, (2).

Rodiyana, Roni. (2016). Growing Democratic Leadership In Elementary Scholl. Proceeding The 3rd Summit Meeting on Education International Seminar. Vol. 1 (Cet. 1).

Rodiyana, Roni. (2018). Analisis Model Cooperative Learning Type Student Facilitator And Explaining Terhadap Hasil Belajar Siswa Sekolah Dasar. Jurnal Cakrawala Pendas. 4, (1), 87-97.

Rodiyana, Roni. (2018). Pengaruh Penerapan Strategi Quantum Learning terhadap Motivasi Belajar dan Pemahaman Konsep Siswa. Jurnal Cakrawala Pendas. 4, (2), 45-57.
Rodiyana, Roni. (2018). Penerapan Metode Pembelajaran VCT (Value Clarification Technique) untuk Meningkatkan Sikap Demokratis Siswa dalam Pembelajaran PKn di Sekolah Dasar. Jurnal Cakrawala Pendas. 5, (1), 8-18.

Roestiyah N.K. (2008). Strategi Belajar Mengajar. Jakarta: Rineka Cipta.

Sanjaya, W. (2008). Perencanaan dan Desain Sistem Pembelajaran. Jakarta: Kencana.

Sugiyono. (2014). Metodologi Penelitian Kuantitatif, Kualitatif, dan $R \& D$. Bandung: Alfabeta.

Sugiyono. (2016). Metodologi Penelitian Kuantitatif, Kualitatif, dan $R \& D$. Bandung: Alfabeta.

Sugiyono. (2016). Metodologi Penelitian \& Pengembangan. Bandung: Alfabeta.

Sujarweni. V. Wiranta. (2014). Metodologi Penelitian. Yogyakarta: Pustaka Baru Press.

Trianto. (2010). Mengembangkan Model Pembelajaran Tematik, Jakarta: PT Prestasi Pustaka.

Tim Penyusun. (2013). Peraturan Menteri Pendidikan dan Kebudayaan Republik Indonesia Nomor 81A Tahun 2013 Tentang Implementasi Kurikulum. Jakarta.

Undang-Undang No. 20 Tahun 2003 tentang Sistem Pendidikan Nasional pada pasal (33). 